\title{
Unstable debt/GDP dynamics as an early warning indicator
}

Citation for published version (APA):

Ziesemer, T. H. W., \& Kool, C. J. M. (2005). Unstable debt/GDP dynamics as an early warning indicator. UNU-MERIT, Maastricht Economic and Social Research and Training Centre on Innovation and Technology. MERIT-Infonomics Research Memorandum Series No. 015 https://doi.org/10.26481/umamer.2005015

Document status and date:

Published: 01/01/2005

DOI:

10.26481/umamer.2005015

Document Version:

Publisher's PDF, also known as Version of record

\section{Please check the document version of this publication:}

- A submitted manuscript is the version of the article upon submission and before peer-review. There can be important differences between the submitted version and the official published version of record.

People interested in the research are advised to contact the author for the final version of the publication, or visit the DOI to the publisher's website.

- The final author version and the galley proof are versions of the publication after peer review.

- The final published version features the final layout of the paper including the volume, issue and page numbers.

Link to publication

\footnotetext{
General rights rights.

- You may freely distribute the URL identifying the publication in the public portal. please follow below link for the End User Agreement:

www.umlib.nl/taverne-license

Take down policy

If you believe that this document breaches copyright please contact us at:

repository@maastrichtuniversity.nl

providing details and we will investigate your claim.
}

Copyright and moral rights for the publications made accessible in the public portal are retained by the authors and/or other copyright owners and it is a condition of accessing publications that users recognise and abide by the legal requirements associated with these

- Users may download and print one copy of any publication from the public portal for the purpose of private study or research.

- You may not further distribute the material or use it for any profit-making activity or commercial gain

If the publication is distributed under the terms of Article $25 \mathrm{fa}$ of the Dutch Copyright Act, indicated by the "Taverne" license above, 


\section{MERIT-Infonomics Research Memorandum series}

\section{Unstable Debt/GDP Dynamics as an Early Warning Indicator}

\section{Thomas Ziesemer}

\section{5-015}

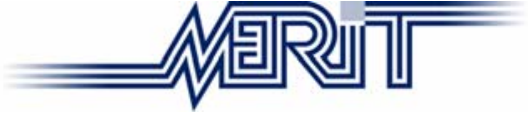

MERIT - Maastricht Economic Research Institute on Innovation and Technology

\section{PO Box 616}

6200 MD Maastricht

The Netherlands

T: +31433883875

F: +31433884905

http://www.merit.unimaas.nl

e-mail:secr-merit@merit.unimaas.nl

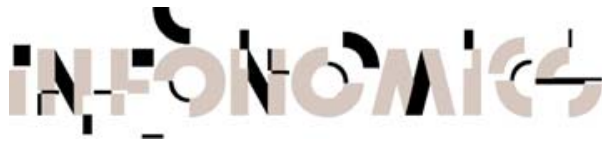

International Institute of Infonomics

c/o Maastricht University

PO Box 616

6200 MD Maastricht

The Netherlands

T: +31 433883875

F: +31 453884905

http://www.infonomics.nl e-mail: secr@infonomics.nl 


\title{
Unstable Debt/GDP Dynamics as an Early Warning Indicator
}

\author{
Thomas Ziesemer, Department of Economics and MERIT, Maastricht University,
}

May 2005

\begin{abstract}
:
In this paper we develop a simple neoclassical growth model with perfect international capital mobility to analyze the stability of the differential equation in the foreign debt/GDP dynamics of developing countries in general and Korea, Malaysia and Thailand in particular in the long run using data over the period 1960-2000, and to use it as a counterfactual for bad times. We show that three different regimes can be distinguished: a stable steady state debtor regime, a stable steady state creditor regime and an unstable regime. A switch from a stable debtor or a stable creditor position to an unstable creditor regime with an increasing debt/GDP ratio is a sign of forthcoming trouble. We investigate this issue empirically for the three Asian countries in the run-up to the 1997 Asia crisis. Over the full sample, the evidence suggests that debt dynamics evolved according to the stable debtor case in each country with an equilibrium value of zero for Malaysia but positive ones for Korea and Thailand. Using a rolling regression technique, we find that indeed occasional switches to the unstable regime occurred. We demonstrate that all three countries investigated here were facing deteriorating domestic fundamentals - reflected in a movement towards unstable debt/GDP dynamics - some years prior to the breakout of the Asia crisis. As such, our approach appears to offer an interesting early warning indicator - the vanishing stability and appearance of instability in the differential equation of the debt/GDP ratio - for financial (debt) crises that should be used together with others for countries with fixed exchange rates.
\end{abstract}

\footnotetext{
* P.O. Box 616, NL 6200 MD Maastricht. T.Ziesemer@algec.unimaas.nl. Phone: ++31-43-3883872. I am grateful to Rainer Haselmann, Stephanie Holle and Clemens Kool for company during and to Bertrand Candelon for useful help and comments on the first, now completely revised, version of this paper.

Responsibility for this paper is entirely mine.
} 


\title{
Unstable Debt/GDP Dynamics as an Early Warning Indicator
}

\begin{abstract}
In this paper we develop a simple neoclassical growth model with perfect international capital mobility to analyze the stability of the differential equation in the foreign debt/GDP dynamics of developing countries in general and Korea, Malaysia and Thailand in particular in the long run using data over the period 1960-2000, and to use it as a counterfactual for bad times. We show that three different regimes can be distinguished: a stable steady state debtor regime, a stable steady state creditor regime and an unstable regime. A switch from a stable debtor or a stable creditor position to an unstable creditor regime with an increasing debt/GDP ratio is a sign of forthcoming trouble. We investigate this issue empirically for the three Asian countries in the run-up to the 1997 Asia crisis. Over the full sample, the evidence suggests that debt dynamics evolved according to the stable debtor case in each country with an equilibrium value of zero for Malaysia but positive ones for Korea and Thailand. Using a rolling regression technique, we find that indeed occasional switches to the unstable regime occurred. We demonstrate that all three countries investigated here were facing deteriorating domestic fundamentals - reflected in a movement towards unstable debt/GDP dynamics - some years prior to the breakout of the Asia crisis. As such, our approach appears to offer an interesting early warning indicator - the vanishing stability and appearance of instability in the differential equation of the debt/GDP ratio - for financial (debt) crises that should be used together with others for countries with fixed exchange rates.
\end{abstract}

\section{Introduction}

After the Latin-American debt crisis in the early 1980s, the risk of debt crises appeared to have disappeared from the scene. However, a series of international crises in the late 1990s have brought the issue back on the agenda. First, the Asia crisis in 1997-98 hit international financial markets, followed by the Russia crisis in 1998 and the Argentinean meltdown in 2001-2002.

Unsurprisingly, a large theoretical and empirical literature has emerged on the analysis of debt, balance-of-payments, currency and banking crises and the relations between them. Much of the literature has been digested into an early-warning-indicator system by Kaminsky, Lizondo and Reinhart (1998). As early warning is a forecasting activity, it is inevitably imperfect. Cumby and Wijnbergen (1989) point out that information on depleting reserves tends to be available when it is too late. Alvaraz-Plata and Schrooten (2004) provide a critical assessment of this system in regard to the Argentinean crisis. Clearly, the important effort of Kaminsky et al. (1998) is likely to need some complementary indicators. In particular, the debt/GDP ratio is not contained in 
their system because the literature they include does not discuss it quantitatively although it is a crucial variable in other empirical and theoretical literature. Reinhart et al. (2003) emphasized the role of the debt/GNP ratio but use gross debt rather than debt net of assets abroad. In contrast to earlier literature, which discussed the level of the gross debt/GDP ratio, we will use the dynamic (in-)stability of the net debt/GDP ratio. We will use it in this paper, because we can show that the information is available fairly early and one can use yearly data and does not depend on monthly data as preferred in the Kaminsky et al. approach and not on quarterly ones as in Markov-regime switching analyses. Another example of the difficulties in forecasting financial crises and country defaults is the 1997 Asian debt crisis. This crisis took many investors completely by surprise. Ex post, wellknown economists claimed that there was merely an irrational financial panic, while the economic fundamentals of the countries in question were solid. In this paper we develop and apply a method to test such claims. In particular, we show in this paper that the above claim may have been a misperception, which could have been avoided using our procedure of testing the stability assumption of the differential equation in the debt/GDP ratio.

To this purpose, we return to a literature that focuses on simple debt dynamics. The model by Amano (1965) is the simplest variant of a model type, which explains the occurrence of debt crises in a neoclassical framework due to shocks. In addition, the model generates conditions under which the traditional idea of a debt cycle can be shown to hold or not to hold respectively. Amano (1965) does not go into details of the debt cycle but rather emphasizes that a country's GNP may grow at a rate larger than the natural one if it saves much and foreign investment (credit) income is a large share of GNP. We will show (i) that analytically the model can show debt crises in the form of a shock, (ii) that a simple dynamic debt process can be derived with several possible outcomes, and (iii) that if theoretically and empirically the debt/GDP dynamics moves towards the unstable cases of the model in times heading for crises, this is in all likelihood essentially a deviation from the model. Therefore the model is a tool that is valid in good times and can be shown not to be valid in bad times ahead. The deviations from the model give a warning. 
These outcomes can be dichotomized as follows. First, a debtor country can be on a stable path towards a steady state. In the final steady state, the country will remain a debtor if its saving ratio is low. Second, it can also become a creditor in the steady state if its saving ratio is high enough. Third, the country can be on an unstable path without ending up in a steady state. In that case, the country can become a permanent creditor again if the saving ratio is high enough. Amano (1965) emphasizes the latter case, in which the country's GNP is dominated by foreign income and grows at a rate higher than the natural rate. Fourth, the country can be situated on the unstable path and experience an exploding debt, inevitably leading to a crisis because debt grows at a higher rate than output and capital. However, within the narrow confines of the model this can only be the case under restrictive and unrealistic assumptions and if observed in the data it essentially means that the model cannot explain that situation and therefore is shown to be unsuitable for this situation. We derive each of these cases from a linear differential equation in debt per unit of GNP. In short, we focus on the (in-) stability of the debt-GDP ratio and by implication on expected, future levels. ${ }^{1}$

Subsequently, we estimate these equations for Korea, Thailand and Malaysia respectively both for the whole period 1960-2000 and for shorter periods. Our purpose is to show that a country's debt dynamics can switch between the stable and unstable paths over time in response to unexpected shocks. Evidence that the country is situated on the unstable path at some point in time potentially contributes to the analysis of its creditworthiness and to the prediction of the possibility of a forthcoming debt crisis. We demonstrate that all three countries investigated here were facing deteriorating domestic fundamentals - reflected in potentially unstable debt dynamics - prior to the breakout of the Asia crisis. ${ }^{2}$ The practical point then is to take the debt/GDP ratio seriously in early warning analysis.

The paper is structured as follows. In section 2 we present the model, which we use to derive the various debt dynamic processes in section 3. In section 4 we present data and estimation procedure for the three Asian countries under investigation. We present and discuss the results in section 5 . The summary and conclusions follow in section 6 .

\footnotetext{
${ }^{1}$ Milesi-Ferretti and Razin (1996b) focus on the current levels.

${ }^{2}$ In a companion paper the same result was achieved for Argentina.
} 


\section{A simple neoclassical growth model with perfect capital mobility}

Trying to construct a model that includes all relevant capital market imperfections is a hopeless undertaking given the many facets of these imperfections that might matter during a crisis. Therefore we start from the opposite, a simple neoclassical growth model with perfect international and national capital markets, and in particular perfect international capital mobility. As pointed out above, we do so in order to have a tool that may be valid in good times and can be shown not to be valid in bad times ahead. The assumption of high capital mobility when capital includes official aid ${ }^{3}$ is supported by Vamvakidis and Wacziarg (1998) using a Feldstein-Horioka framework. ${ }^{4}$ On the other hand, Basu (1991) has pointed out that there are times of credit rationing with capital supply below the Walrasian level and other times of loan pushing with capital supply larger than the Walrasian level. Ziesemer (1997) has shown that ups and downs in world market interest rates may produce switches from loan pushing to credit rationing and vice versa in Basu's model. Of course, some countries may always be rationed severely ${ }^{5}$ but the Asian countries considered here, which belong to the set with no external default history (see Reinhart et al. 2003), at times had debt/GDP ratios as high as $40 \%$ or even 60\% in the 1990s (see Appendix B: Data), which hardly indicate rationing but rather did often raise the question whether or not these countries get too much money. By implication, Walrasian levels can be expected roughly on average but not systematically in all sub-periods. We expect debt/GDP ratios to grow at increasing rates before crises but at decreasing rates in good times. This idea is captured by the following model.

Due to the assumption of perfect international capital mobility, the domestic interest rate is given at the level of the world interest rate. In addition, we assume that output $(Y)$ is produced by the production factors capital $(K)$ and labor $(L)$ with labor-

\footnotetext{
${ }^{3}$ Without this assumption recent trends make non-rationing a much less plausible assumption for several countries. See Evrensel 2004 for recent trends.

${ }^{4}$ More recent literature has given a different interpretation to the Feldstein-Horioka type of results (see Coakley et al. 1999 and Kasuga 2004).

${ }^{5}$ Lane (2004) provides some empirical support for credit rationing. However, we could imagine that his regression results may be explained by models using production functions with debt but without rationing, because they also would have a correlation between output and debt. The data do not contradict the idea of credit rationing though. Eaton and Gersovitz (1981) also found credit rationing for many although by far not for all countries using a disequilibrium econometrics approach.
} 
augmenting technology $(A)$. The production function is linearly homogeneous with positive first and negative second partial derivatives:

$Y=F(K, A L)$

Profit maximization of the representative firm yields the marginal productivity condition $r=f^{\prime}(k) \quad$ with $\quad k \equiv K / A L \quad$ and $\quad \hat{K}=\hat{A}+\hat{L} \equiv g \geq \hat{L}$

Since $r$ is given and for simplicity constant over time ${ }^{6}$, the marginal productivity condition determines the capital/efficient-labor ratio as a constant. The capital stock $K$ consists of domestic capital $W$ and foreign capital or debt $D$. Conditional on the level of the domestic stock of capital $W$, the country can choose its desired level of foreign indebtedness $D$ to make equation (2) hold at any moment. The labor force $L$ is assumed to grow at rate $n$. In the steady state the capital stock $K$ and output $Y$ grow at the same constant rate $g$, keeping $k$ constant if the interest rate is constant.

We assume goods market equilibrium to hold. In a small open economy under perfect capital mobility, the country then can finance any domestic investment in excess of national savings through the international capital market. Excess investment results in an equal increase in the country's international indebtedness, as reflected in equation (3):

$\dot{D}=\dot{K}-S$,

Dots indicate the change in a variable per unit of time. Domestic savings is assumed to depend on the country's income net of foreign interest payments, with marginal propensity to save equal to $s$ :

$S=s(Y-r D)$,

Combining equations (2)-(4) yields a differential equation for the change in the country's external debt per period.

$\dot{D}=g K(0) e^{g t}-s\left[Y(0) e^{g t}-r D\right]$

\footnotetext{
${ }^{6}$ This seems to be plausible for the long-run average, but not for the short run.
} 
For a formal treatment of this differential equation extended to include a rate of depreciation we refer to Appendix A. Note that these debt dynamics are derived from the goods market equilibrium condition and therefore reflect only the 'fundamentals': investment and savings. The implied absence of an impact of the balance of payments, in particular the trade balance, on investment and savings is only plausible as long as exchange rate problems are absent. ${ }^{7}$ Consequently, we would expect the model to perform badly in an empirical sense when exchange rate problems are present. We explain this in the following sections.

\section{Debt cycle versus permanent debtor position}

First, we slightly rewrite equation (3’). From the marginal productivity condition (2), we see that in case of a constant elasticity of substitution $(C E S)$ production function $r=\beta$ $(Y / K)^{1-\rho}$ where $\rho$ is the CES parameter and $\beta$ is the elasticity of production of capital if $\rho$ $=0$, i.e. in the Cobb-Douglas case. ${ }^{8}$ Solving the marginal productivity condition for $Y$ and substitution of $Y(0)$ leads to:

$$
\dot{D}=K(0)\left[g-s(r / \beta)^{1 / 1-\rho}\right] e^{g t}+s r D
$$

Subsequently we express $D$ in terms of $G D P(Y)$. To this purpose, we first divide both sides of equation (3') ) by $D$, subtract $g$ - the steady-state growth rate of $Y$ - and then multiply by $D / Y .^{9}$ The result is:

$$
\dot{d}=\underline{k}\left[g-s(r / \beta)^{1 / 1-\rho}\right]-[g-s r] d
$$

\footnotetext{
${ }^{7}$ Note that this model shares the dominance of capital movements over the impact of the trade balance with those of the Keynes-Mundell-Fleming and its successors under high capital mobility and the YaariBlanchard-Weil type. This feature is not purely a typically neoclassical one.

${ }^{8}$ This expression is only used to eliminate $\mathrm{Y}(0)$ in (3'). We use $Y=\left[\beta K^{\rho}+(1-\beta)(A L)^{\rho}\right]^{1 / \rho}$.

${ }^{9}$ Alternatively, we may express $D$ as a percentage of the stock of efficient labor $(A L)$. Equation (5) is unaltered by this transformation, apart from the definition of $d$, which now is $D / A L$. Unreported results show that our empirical results are qualitatively the same for both definitions of $d$. We prefer to use GDP as the denominator as both GDP and $D$ are generally available in US\$, whereas $A L$ is only available in real terms. Hyperinflationary periods make conversion much more problematic when $A L$ is used to normalize.
} 
$d$ denotes the ratio of debt over GDP $(D / Y)$. In equation (5), $\underline{k}$ is the constant value of the capital-output ratio corresponding to equation (2). The sign and size of the slope and the intercept depend on the (unobserved) parameters $g, s, \beta, \rho$ and $r$ and can be positive or negative. The three possible cases - corresponding to the different stable and unstable paths of the differential equations - are shown in Figure 1. In this figure $d$ is on the horizontal axis, while $\dot{d}$ is on the vertical one.

\section{FIGURE 1 OVER HERE}

If $s(r / \beta)^{1 /(1-\rho)}>g>s r$, assuming $r / \beta<1$ and $\rho<0,{ }^{10}$ both the slope and the intercept are negative. The corresponding line in Figure 1 is indicated by SC. The stable stationary point (I) is at negative values of $d$, implying that the country becomes a creditor in the long run. In point I, the ratio of foreign wealth $(D)$ to GDP is constant if there are no more shocks. Both $D$ and $Y$ grow at the same rate $g$. Since $D$ is negative, it implies that the country holds positive net foreign assets in the steady state. Suppose the country starts out as a debtor at positive values of $d$. Subsequently, $d$ will decrease to converge to the steady state along line SC. It can be easily shown using Appendix A that initially the level of external debt D will still grow - though at a slower pace than GDP corresponding to a current account deficit. Over time, the current account deficit is reduced and turns into a surplus with reduction in $D$. This case is the traditional view on the debt cycle in which every country eventually becomes a creditor (non-debtor).

If $\mathrm{g}>s(r / \beta)^{1 /(1-\rho)}$, and $g>s r$, the slope remains negative, but the intercept becomes positive. This case is captured by line SD in Figure 1. Now, the country converges to a steady state (II) where $d$ is positive. The economy remains a debtor because of its low savings ratio and/or the low world interest rate. The low savings rate forces the country to externally finance its domestic investment, while the low world interest rate helps to reduce the cost of doing so. In the steady state, $D$ again grows at the rate $g$, which implies that the country remains a capital importer. The current account is

\footnotetext{
${ }^{10}$ In case of a Cobb-Douglas function we have $\rho=0$ and $s r / \beta>s r$, with beta as the elasticity of production of capital. For the empirically relevant negative CES parameters with an elasticity of substitution smaller than unity and assuming $r / \beta<1$, which seems empirically reasonable, we get $s(r / \beta)^{1 / 1-\rho}>s r$. CD and CES don't make a big difference here.
} 
not balanced in the long run unless the horizontal intercept of the differential equation is at the origin. ${ }^{11}$

If $g-s r<0$, the slope is positive and the vertical intercept is negative. This is the unstable case, labelled $U$ in Figure 1. By implication, $g-s r>0$ is a stability condition, but obviously, there is no reason to a priori impose such stability assumption. The stationary but unstable point (III) is at a positive value of $d$. If $d(0)$ is less than in the stationary point, the economy starts moving to the region of negative and continuously declining $d$. In that case, the country will be a creditor in the long run, where GNP grows faster than GDP. This is the point Amano (1965) made.

A starting point to the right of the stationary point implies that $D(0)$ sufficiently exceeds $K(0)$, unless the elasticity of substitution is larger than unity, as shown in appendix A, where the model is extended to have a positive rate of depreciation. Clearly an unstable case is unsustainable in the longer run because for a constant interest rate, interest payments, $r D$, would become larger than the GDP. A country on such explosive path will be forced to adjust, one way or the other. ${ }^{12}$ As $D(0)>K(0)$ or a more mild condition under an elasticity of substitution larger than unity seems to be an unrealistic case from an empirical point of view we will interpret explosive debt dynamics in the data as a case of deviation from our model for good debtors in good times.

In this type of model, a switch from one dynamic process - say the SD line - to another - say the SC line - can only arise due to changes in the underlying parameters of the system, $g, s, r, \beta$ and $\rho$. As an example, we will now discuss a non-anticipated and permanent upward jump in the world interest rate. If this happens, the marginal product of capital will increase and the optimal amount of capital $K$ to be used will fall. For a given national wealth $W$, a fall in the desired level of capital $K$ implies that less external

\footnotetext{
${ }^{11}$ In the literature it is often assumed that the current account must be balanced in the long run, based on the assumption that creditors will try to increase their welfare by not allowing other countries to borrow permanently (see Cohen 1991). Whether this is the case, however, is an empirical as well as a theoretical question. In our model we do not explicitly impose the restriction of a balanced current account. In contrast early warning is a problem exactly because the question is when and how creditors should react. Closely related is the issue that the approach using an explicit intertemporal budget constraint does not tell when countries have to leave a non-sustainable path because the central conditions are asymptotic ones. No approach so far - including our own - gives an indication on when to react.

${ }^{12}$ Neher (1970) assumes that debt $d$ grows at the same rate as the capital stock. As we have shown, this is only the case in the steady states of the stable cases. Amano (1965) has treated only the left arm of the unstable case. Our model integrates all these cases.
} 
debt $D$ is required. As a result less debt is obtained from the international capital market. Alternatively stated, it implies that more domestic wealth is invested abroad at the higher world interest rate level. Such a decrease in capital inflows or increase in capital outflow - even capital flight - thus can be rooted in the economy's fundamentals and need not be a purely monetary phenomenon of (ir-)rational speculators. Domestically, the resulting lower marginal product of labor leads to a fall in real wages. This is the social side of the crisis or shock.

We can also describe these dynamics of an interest shock in terms of differential equation (5) and Figure 1. Start from a situation where the country is a long-run debtor (the SD line). A jump in the interest rate leads to both a counter-clock wise rotation (flatter slope) and a downward shift of the SD line. The economy can move from the situation $\mathrm{g}>s(r / \beta)^{1 /(-\rho)}>s r$ (SD in Figure 1) to a situation $s(r / \beta)^{1 /(1-\rho)}>g>s r$ (SC) or even to a situation $s(r / \beta)^{1 /(1-\rho)}>s r>g(\mathrm{U})$, depending on the size of the interest rate shock.

A similar analysis can be given for other exogenous events changing the slope and intercept of the differential equation, like for instance a jump in the savings rate $s$ or in the rate of population growth $n$ or technical change, which in turn changes $g$.

In the empirical part of our paper, we will present evidence on the extent to which Korea, Malaysia, and Thailand respectively have switched between the different regimes of debt dynamics over the period until 1997. The empirical equivalent of equation (5) that we use in our estimation is:

$$
\dot{d}=\alpha_{0}+\alpha_{1} d(-1)
$$

with $\alpha_{0}=\underline{k}\left(g-s(r / \beta)^{1 /(1-\rho)}\right), \alpha_{1}=s r$ - $g$. Clearly, the regression coefficients are complex functions of behavioural parameters, and exogenous but time-varying variables like the world interest rate and the savings rate. Without additional information on these parameters and variables, we can just report the regression estimates and account for potential time-variation. If more information were available, an extended regression equation could be estimated. For instance, if adequate information on interest rate $r$ could be used, one could (nonlinearly) regress $\dot{d}$ on $d(-1), r$, and $r^{*} d(-1)$. We leave such 
exercises for future research. Note also that the explanatory variable in equation (6) is lagged one year. This is due to the switch from the continuous-time derivation of our theoretical model to the discrete-time formulation of the empirical model.

\section{Data $^{13}$}

For our analysis, we need the stock of external debt and the level of GDP for each country. While GDP is readily available both in current and constant prices, this is not the case for developing country's net stock of external debt. What is available is the time series of gross investments and savings for each country. These are flow variables and the difference between the two can be used to calculate the change in a country's debt position $(D)$. Cumulating them gives the stock of net debt. The only problem is to have an initial value of $D$. In order to arrive at an adequate measure of the initial value of $D$, we focus on the year 1980 as the benchmark year. The procedure is as follows for each country.

\section{TABLE 1 OVER HERE}

First, we use the IMF International Financial Statistics yearbook to find investment income paid to the rest of the world and investment income from abroad in 1980 for each country. The difference corresponds to $r D$ in our model. ${ }^{14}$ For an estimate of the initial value of $D$, an appropriate value for the interest rate $r$ is needed. To obtain an estimate of $r$, we compute the ratio of interest payment abroad in 1980 to the gross stock of external debt in 1980 both according to the Global Development Finance (2003) database. ${ }^{15}$

\footnotetext{
${ }^{13}$ Data without explicitly mentioned sources are from World Development Indicators. As our analysis refers to the Asian debt crisis we do not need the more recent data.

${ }^{14}$ For Korea income credit for 1980 according to IMFIFSY 1997 deviates considerably from that in IMFIFSY 2001. We take the value from the 1997 statistics, because these were available in 1997 and 1996. The initial value for 1980 thus obtained is about the same as the cumulated sum of investment minus savings from 1960-1980 without any initial value.

${ }^{15}$ Note that the stock of debt in the GDF data base is not net but gross of wealth held abroad. This is clear from the conceptual explanations there, the definition taken over into the World Development Indicators (2002) and of course from the differences of our numbers for net debt and the external debt number in the GDF. Anyway, our model contains net debt, of course. The gross debt/GNI ratio of the GDF therefore does not correspond to what we have in the model. Gross debt should not be used in crisis analysis because it may be covered by assets abroad in the vein of two-way capital flows, which are one feature of globalization. When covered by assets abroad they cannot signal problems (International trade in equity is an example. It is a financial transaction which has no net effect on net debt, because one asset is exchanged against the other if a country other than the USA pays in dollars). When not covered by assets abroad debt can signal problems but that then is debt net of assets held abroad as we use it. For the relevance and data of the difference between net and gross, see Obstfeld and Taylor 2002, p.57-60. For other purposes the use
} 
Dividing net interest payments $(r D)$ by the computed interest rate yields a net foreign debt position $D$ as an initial value for 1980. Table 1 summarizes the steps for making initial values. For Malaysia Table 1 contains three results. The reason is that income debit according to IMFIFSY deviates unusually much from interest paid according to the GDF (2003). In the column for Malaysia1 we divide the interest paid according to the GDF by the total debt stock also according to the GDF because use of one data source is more likely to be consistent. The result is a reasonable interest rate of almost $9 \%$ but also extremely high debt/GDP ratios for the 1960s. In the column Malaysia2 we divide income debit from IMFIFSY by the total debt stock from GDF (2003). The result is a high interest rate of almost 24\% and a lower but still high debt/GDP ratio for the 1960s starting from 2.67 as shown in Appendix B. Subsequently, we cumulatively add (subtract) the nominal gross investment-savings balance for later (previous) years.

Cumulating current account deficits generates very similar data (except for Malaysia in the year 2000), when using the same initial value. Deviations may result from the possibility to pay for deficits by reduction of reserves or to enhance debt flows for the sake of increasing reserves. The resulting debt series is divided by nominal GDP (in mln US \$) to arrive at our series $d$ (and its first difference $\mathrm{d} d$ ). Note that using the revalued Net International Investment Position (NIIP) data of Lane and Milesi-Ferretti (2001) would require revaluing the GDP data in a similar way in regard to exchange rates. However, NIIP data in IMFIFSY do not suggest reliability for the countries in question. For savings we use those data including net current transfers and net current income as early as possible. For the earlier period before the middle of the seventies we use those not including net current transfers.

\section{FIGURE 2 OVER HERE}

Appendix B contains the data, where the 1980 debt position is printed bold to indicate its benchmark role. In the column Malaysia3 in Appendix B we have just used an arbitrarily imposed initial value of zero. The time paths of debt/GDP ratios for each country can be found in Figure 2. Korea experiences a relatively steep decline in its debt ratio between 1985 and 1988. Subsequently, a gradual rise takes place to a peak in 1997. After the crisis, the debt ratio declines quickly. The debt ratios of Malaysia and Thailand are quite 
similar after 1980. First, they show a rise till the mid 1980s, followed by a decline. The latter is steeper for Malaysia than Thailand. After 1989 a similar gradual rise in debt ratios occurs in the three countries. The Asian crisis leads to a turn around in Malaysia and Thailand as it did in Korea. From 1998 onwards, all debt ratios fall. In the 1990s, the level of the debt ratio is considerably lower in Korea than in the other two countries. Note that a rising debt ratio is not necessarily a sign of a forthcoming crisis according to our theoretical model. A country on the left arm of the stable debtor (SD) line in Figure 1 would be characterized by a combination of a rising debt ratio and a declining (but positive) change in the debt ratio. It is when the level of the debt ratio and the change in the debt ratio increase together and falls outside the realm of the model we get an unstable time path. Given all that has been written on debt, currency and balance of payments crises this is most critical when countries have fixed and overvalued exchange rates (see Kaminsky and Reinhart 1999). Practical applications should focus on this combination as we do in this paper and in our companion paper on Argentina, because fixed, overvalued exchange rates and increasing debt/GDP ratios were present in all of these cases as well as in the most strongly affected countries during the Latin American debt crisis in the 1980s.

\section{Empirical Results}

We first estimate equation (6) for Korea, Thailand and Malaysia2 over the sample period, 1961-2000. The first column for each country in Table 2 contains the results for ordinary least squares estimates. The point estimates of slope and intercept are consistent with the stable dynamics of our theoretical model. For Thailand, the strongest results are obtained.

TABLE 2 OVER HERE

The intercept is positive and significant according to standard critical values, while the slope coefficient is significantly negative. It suggests that Thailand had debt dynamics consistent with the stable debtor case. For Korea and Malaysia, the significance of the results is weaker and intercept coefficients are insignificant. Both slopes are significantly negative. Since the intercepts are not significantly different from zero, the evidence suggests a steady state debt ratio of about zero, implying these countries would neither be a debtor nor a creditor. This is in accordance with the model. In equation (5) a zero 
intercept requires a negative slope. The relation between the formulas in equation (5) for the two parameters in equation (6) is fully confirmed by these estimates. Temporary deviations from this (shown below) are therefore deviations from the (long run trend of the) model. A caveat is in order, however. The dynamic specification of equation (6) can be interpreted as a simple Dickey-Fuller unit root test - or equivalently a stability test of the debt ratio without a time trend as in the model. It is well known that standard critical values are invalid in case the dependent variable in fact is non-stationary. Moreover, the Durbin Watson statistics suggest a considerable amount of serial correlation in the residuals for each country that needs to be accounted for. Therefore, we run an augmented Dickey-Fuller (ADF) unit root test including additional lags of the dependent variable as in standard unit root tests. The results are in the second column for each country in Table 2. Using the correct 1 percent MacKinnon critical t-values, we reject a unit root for all three countries. Nevertheless, the results in terms of sign and size of the intercepts and slopes are qualitatively similar to the original simple regression but they are all significant now, with the exception of the intercept of Malaysia, which we therefore have put to zero. The ratio of the intercepts and the slopes gives the stable steady-state value for each country: $18.6 \%$ for Korea, $60 \%$ for Thailand, and zero for Malaysia2. Again this is in accordance with the model. Using data from 1975 onwards though (leaving us with 26 observations only) gives a much larger probability for unit roots. This is probably due to the more weird times including the oil crises, the Latin American debt crisis, the top value of the dollar in 1985, and the Asian crisis in 1997/98.

In fact, we are interested exactly in the issue if and when countries switch between regimes and to what extent it contributes to predicting that we are moving into the direction of a crisis (from stable debtor to stable creditor to an unstable situation). Therefore, we would like to identify the sub periods over which different regimes were operative. But small sample problems then become more serious than in the full sample case.

Before presenting some evidence of time-variation in the debt dynamics in Korea, Malaysia and Thailand, we shortly discuss the routes we explored but not used in the end. First we re-estimated equation (6) with dummy variables for both intercept and slope for economically plausible sub periods for the sub periods. As could be expected, results 
failed to gain significance due to the lack of degrees of freedom. Moreover, we could not be sure we had picked the right timing of regime switches. More sophisticated methods to endogenously determine the timing of structural breaks were inapplicable due to the short time series. ${ }^{16}$ Second, we tried Markov regime-switching. Neither approach yielded convergence or interpretable results, again due to the short length of our time series.

Therefore, we turned to a rolling regression approach, where equation (6) is estimated for consecutive windows of six, seven, and eight years respectively. In Table 3 we present the time paths for estimated intercept and slope of the Korean debt dynamics. Tables 4 and 5 contain corresponding information for Thailand and Malaysia respectively. Due to the small samples and the change in the coefficients, regressions coefficients typically fail to gain significance. We present t-values because readers of an earlier version asked for them. In the discussion, we focus on the point estimates of intercept and slope.

\section{TABLE 3 OVER HERE}

\subsection{The 1997 Asia Crisis}

The overall pattern in Tables 4-6 is that in the first three periods of the six, seven and eight years intervals respectively and for each country the sign of the slope is negative, indicating stability, and the last two are positive, indicating instability. The exceptions to this rule are indicated by bold numbers. These exceptions imply that for Thailand there is an undue warning at the end of 1993 from the six years windows, which is not supported by the other windows though. Furthermore, seven years windows warn one period too late (only at the end of 1997) and eight years windows one period earlier. For Korea six years windows warn one period too late in terms of signs, but the slope has decreased already before. For Malaysia the warning through a positive sign is later in all windows. But the slope coefficients are falling continuously according to the seven and eight-year windows. A late warning is also plausible to the extent that Malaysia was affected mainly in the vein of contagion effects coming from Thailand, but its current account was also strongly negative (see below). In all cases, the debt/GDP ratio and its change were positive and the differential equation is therefore on the side of explosive debt/GDP when the estimate of the slope is positive.

\footnotetext{
${ }^{16}$ See Bai and Perron (1998) and Perron and Vogelsang (1992) for such methods.
} 


\section{FIGURE 3 OVER HERE}

The Asian crisis started in Thailand. In May 1997 the central bank of Thailand imposed new restrictions on international capital flows. July $2^{\text {nd }}$, the bath devalued. Malaysia and Korea followed later that year. We start with a more detailed discussion of the results for Thailand in Table 4, as that country was the first one in crisis. In 1996, the 6-year window shows an upward surge in the slope estimate, which is reinforced when the crisis year 1997 is included. The IMF talked to Thailand already in February 1997. The data underlying Appendix B in Figure 3 show that the discrepancy between domestic savings and investments was growing steadily between 1992 and 1996, especially due to increased investment. Both, the debt ratio and its change were increasing since 1993 (see appendix B) indicating that the economy was on the unsustainable arm of the unstable debt dynamics. Only after the decline in stock and real estate prices in 1997 do investments return to the overall savings level and below it. In summary, we conclude that the debt situation in Thailand was deteriorating since the early nineties. At the minimum, it provided an early warning of a potentially unsustainable development at the end of 1996.

\section{TABLE 4 OVER HERE}

Korea was hit a few months later than Thailand. It has been suggested that contagion effects due to herd behaviour of foreign investors was the main source of the Korean crisis. However, the regressions coefficients in Table 3 do show an upward trend, getting less negative in the slope estimate, in the mid 1990s. Starting in 1994 the slope estimate rises. It is around zero in 1996 and positive in 1997. For the 7-year and 8-year windows, the increase of the slope starts later, but is more pronounced. In 1996, the slope estimate in the 7-year and the 8-year window exceeds zero. Similar to Thailand, the Korean debt ratio increased substantially prior to 1997. The gap between investment and domestic savings increased six fold. While the development of the Korean debt dynamics points at a potentially unstable debt path, we do note that the level of the debt ratio was quite low compared to Thailand and Malaysia. In that respect, we cannot exclude the possibility that the events in Thailand played a role in triggering the crisis in Korea. The deteriorating fundamentals in Korea nevertheless provided a fertile soil.

TABLE 5 OVER HERE 
For Malaysia, the picture is somewhat less clear, though the estimated slope coefficients are similar to the Korean ones in the mid 1990s. The first signs of deteriorating fundamentals - as reflected in rising slope coefficients - only become visible after 1994, because the debt ratio and its change are increasing from 1992 through 1997 with the exception of 1996. The slope gets positive in 1997 for the 6-year and 8year windows. This is fairly late but slopes increase in \& and 8 years windows before. The results also point at potential instabilities around 1985 (not shown) when all windows show a peak in the slope coefficients. For the 7-year and 8-year windows, the coefficient is about zero in 1985. Glick and Hutchison (2001) report a banking crisis in Malaysia in 1985-1988 and a currency crisis in 1986. Our approach apparently is able to pick up the risk of such crises slightly before.

In general, the data and our empirical results suggest that switches to undesirable and unstable debt dynamics tend to be sudden and short-lived, making them hard to predict. Cross-country comparison of the estimated intercept and slope coefficients in a given year is hampered by the relatively large standard deviations of the coefficients. We do show, however, that the different qualitative regimes of the theoretical model can be observed in reality. Intercepts and slope coefficients are almost always of opposite signs. When the intercept is positive and the slope negative the country is in a stable debtor regime. When intercepts are negative and slopes are positive, explosive debt is indicated if the debt/GDP ratio and its change are both positive. Shortly after, the crisis hits and stabilizes the debt dynamics. More in particular, we demonstrate in Figure 3 and 4 that all three countries investigated here were facing deteriorating domestic fundamentals prior to the breakout of the Asia crisis. In Korea the difference between investment and savings is largest in 1996 where it is US\$ 22 billion. This is a lot of money for one year only and contributes to a $4.4 \%$ deficit of the current account as percentage of the GDP. Essentially savings stop growing in 1996 whereas investment does not. In Thailand the discrepancy is US\$11 billion which corresponds to a deficit of the current account of $8 \%$ of the GDP. In Malaysia we have US\$ 3.5 billion and the corresponding number for the current account in 1995 is $9.7 \%$ of the GDP. More than 5\% does normally 'flash a red light' (Milesi-Ferretti and Razin 1996a). Although it is reduced to 4.4\% in 1996 it is going to 
5.9\% again in 1997. There is little reason to say that the fundamentals of Malaysia were sound.

\section{FIGURE 4 OVER HERE}

The debt/GDP ratios of our regression analysis clearly have there counterpart in the behaviour of investment and savings of these countries. This suggests that internal problems probably played a significant role with respect to the timing of the crisis. However, they may be induced by overvaluations of the currency, which generates an incentive to buy more imported investment and consumption goods thereby inducing higher investment and lower savings. Budget deficits are below 3\% since 1994 with the exception of Malaysia 1994 (see Figure 5) and therefore the increase in the difference between investment and savings is due to private and not public decisions. That does not exclude the possibility that non-fundamental behaviour of international investors had an independent effect. For each of the three countries, our simple approach did manage to give some advance warning of potentially dangerous developments. Other periods for which we find deteriorating debt fundamentals coincide with crisis periods as reported in Glick and Hutchison (2001). Additional research covering more countries and longer periods is needed to determine the robustness and reliability of our approach. Nevertheless, the first results are promising.

\section{FIGURE 5 OVER HERE}

\section{Conclusion}

In this paper we develop a simple neoclassical growth model with perfect international capital mobility to analyze the international debt dynamics of developing countries in the long run and - by using it as a counterfactual - the events in Korea, Malaysia and Thailand in the run-up to the 1997 Asia crisis.

We show that three different regimes can be distinguished: a stable regime where the country in the end always converges to a steady state debtor position, a stable regime where the country ends up in a steady state creditor position and an unstable regime which leads the country either to become a creditor without ever reaching a steady state or to get on an unsustainable path with an exploding debt ratio. Switches between these regimes can be caused only by shocks in the world interest rate or behavioural parameters like the country's savings rate or rates of population growth and technical progress. 
A switch from a stable debtor to a stable creditor or even an unstable creditor regime of a growing debt ratio is a sign of forthcoming trouble. If one would be able to identify such shift in advance, it would contribute to our ability to predict debt crises and to our understanding of such crises.

To investigate this issue empirically, we construct debt ratio series for Korea, Malaysia and Thailand over the period 1960-2000. Subsequently, we use these series to do the simple debt dynamics regression derived from the theoretical model. Over the full sample, the evidence suggests that debt dynamics evolved according to the stable debtor case for Thailand and Korea and the debt/GDP ratio would go to zero in Malaysia.

Using a rolling regression technique, we find that indeed occasional switches to the unstable regime occurred. We demonstrate that all three countries investigated here were facing deteriorating domestic fundamentals prior to the breakout of the Asia crisis. These are reflected in a shift from negative to positive slopes of the differential equation in the debt/GDP ratio and the implied loss of its stability. It suggests internal problems probably played a significant role with respect to the timing of the crisis. That does not exclude the possibility that non-fundamental behaviour of international investors had an independent effect. For each of the three countries, our simple approach did manage to give some advance warning of potentially dangerous developments. Other periods for which we find deteriorating debt fundamentals coincide with crisis periods as reported in Glick and Hutchison (2001).

In general, our model appears a useful tool of the analysis of a country's debt dynamics. Additional research covering more countries and longer periods is needed to determine the robustness and reliability of our approach. Extending the theoretical model to include for instance interest rate spreads and economic features that are typical of developing countries such as imported capital goods, which would link the goods market equation to the balance of payments equation provide another route for additional research. Nevertheless, the first results are promising in our view and temporary loss of stability of the debt/GDP ratio should and can be used easily by practitioners given the simplicity of the tools, which can easily be updated once the initial values are constructed. 


\section{References}

Alvarez-Plata, P. and M.Schrooten (2004), Misleading indicators? The Argentinean currency crisis, Journal of Policy Modeling 26, 587-603.

Amano, A. (1965), International Capital Movements and Economic Growth, Kyklos, 693699.

Bai, J., and P. Perron (1998), Estimating and Testing Linear Models with Multiple Structural Changes, Econometrica, January, vol. 66, 47-78.

Basu, K. (1991), The International Debt Problem, Credit Rationing and loan pushing: Theory and Experience, Princeton Studies in International Finance, No.70, October.

Coakley, J., F. Hasan and R.Smith (1999), Saving, Investment, and Capital Mobility in LDCs, Review of International Economics 7(4), 632-640.

Cohen, D. (1991), Private Lending to Sovereign States: A Theoretical Autopsy, MIT Press Cambridge, Massachusetts, London, England.

Cumby, R.E. and S. van Wijnbergen (1989), Financial Policy and Speculative Runs with a crawling peg: Argentina 1979-81, Journal of International Economics, August 1989, v. 27 , iss. 1-2, pp. 111-27.

Eaton, J. and M. Gersovitz (1981), Debt with Potential Repudiation: Theoretical and Empirical Analysis, Review of Economic Studies, Vol.48, 289-309.

Evrensel, A.Y. (2004), Lending to developing countries revisited: changing nature of lenders and payment problems, Economic Systems 28, 235-256.

Glick, R. and M.M. Hutchison (2001), Banking and Currency Crises: How Common are Twins?, in R.Glick, R. Moreno, and M.M. Spiegel (eds.): Financial Crises in Emerging Markets, Cambridge University Press, 2001, pp. 35-69.

Hori, H. and J.L. Stein (1977), International Growth with Free Trade in Equities and Goods, International Economic Review, vol.18, no.1, February, 83-100.

IMF (2000), Balance of Payments Statistics, Washington.

Kaminsky, G., S.Lizondo, and C.M. Reinhart (1998), Leading Indicators of Currency Crises, IMF Staff Papers, Vol.45, No.1, March.

Kaminsky, G. and C.M. Reinhart (1999), The Twin Crises: The Causes of Banking and Balance-of-Payments Problems, American Economic Review 89, No.3, 473-500. 
Kasuga, H. (2004), Saving-investment correlations in developing countries, Economics Letters 83, 371-376.

Lane, P.R. (2004), Empirical Perspectives on Long-Term External Debt, Topics in Macroeconomics, Vol.4, Issue 1, 1-21.

Lane, P.R. and G.M. Milesi-Ferretti (2001), The external wealth of nations: measures of foreign assets and liabilities for industrial and developing countries, Journal of International Economics 55, 26-294.

Milesi-Ferretti, G.M. and A. Razin (1996a), Sustainability of persistent current account deficits, NBER WP 5467, February. (1996b), Current Account Sustainability: Selected East Asian and Latin American Experiences, NBER WP 5791, October.

Neher, P.A. (1970), International Capital Movements along Balanced Growth Paths, The Economic Record, September, 393-401.

Obstfeld, M. and A.M. Taylor (2002), Globalization and Capital Markets, NBER WP 8846, March.

Onitsuka, Y. (1974), International Capital Movements and the Patterns of Economic Growth, The American Economic Review, vol. 64, no. 1, March, 24-36.

Perron, P. and T.J. Vogelsang (1992), Nonstationarity and Level Shifts With an Application to Purchasing Power Parity, Journal of Business and Economics Statistics, July, 10, 301-320.

Reinhart, C.M., K.S. Rogoff, M.A.Savastano (2003), Debt Intolerance, Brookings Papers on Economic Activity, 1, 1-62.

Vamvakidis, A. and R.Wacziarg (1998), Developing Countries and the Feldstein-Horioka Puzzle, IMF WP/98/2, January.

World Bank (2002), Global Development Finance, Washington.

World Bank (2002, 2004), World Development Indicators, Washington.

Ziesemer, T. (1997), From Loan Pushing to Credit Rationing: Interest Shocks in a Model by Basu. Journal of Institutional and Theoretical Economics, September 1997, 569-78. 


\section{Appendix A: Solution of the differential equation}

The differential equation has the solution

$D(t)=D(0) e^{s r t}+K(0) B\left(e^{g t}-e^{s r t}\right)$

with $B \equiv\left(g+\delta s-s((r+\delta) / \beta)^{1 /(1-\rho)}\right) /(g-s r)$. In the long run the larger of the two growth rates will dominate the process:

$\lim D(t)_{t \rightarrow \infty}=$

$e^{g t} K(0) B=K(t) B \quad$ if $\quad g-s r>0$, or $\quad e^{s r t}[D(0)-K(0) B] \quad$ if $\quad g-s r<0$

As $s[(r+\delta) / \beta]^{1 /(1-\rho)}>s r$ for $\rho<0$ as assumed here, we can distinguish the four cases of Figure 1 . An unstable case with exploding debt/GDP ratio would require $s r>g$ and $D(0)-K(0) B>0$. For $\delta$ and $\rho$ both close enough or equal to zero we would have $B>1$ and therefore $D(0)>>K(0)$ would be required. This case is fairly unrealistic because it implies that the country has negative current wealth from the beginning and through eternal times while we see from the data that all countries have positive savings at almost all times with only very short periods of exceptions.

The more general case is more complicated. Combining g-sr $<0$ and $\mathrm{B}<1$ in order to allow for $D(0)<K(0)$ requires either that $\rho>1$, which means that substitution goes the wrong way, or that the elasticity of substitution is larger than unity. This can be shown as follows:

$B \equiv\left(g+\delta s-s((r+\delta) / \beta)^{1 /(1-\rho)}\right) /(g-s r)<1$, with $g$-sr $<0$ implies

$g+\delta s-s((r+\delta) / \beta)^{1 /(1-\rho)}>g-s r$; cancelling $g$ and switching terms to the other side yields:

$(r+\delta)_{s}>s((r+\delta) / \beta)^{1 /(1-\rho)}$; cancelling $s$ and taking natural logs on both sides yields

$\ln (r+\delta)>[1 /(1-\rho)] \ln ((r+\delta) / \beta)$

As the case $1-\rho<0$ takes substitution the wrong way, we assume1- $\rho>0$. Multiplication by $(1-\rho)$ then yields

$(1-\rho) \ln (r+\delta)>\ln (r+\delta)-\ln \beta$ or $-\rho \ln (r+\delta)>-\ln \beta$

Case 1: As the log expressions are negative, in the second version of the inequality, a negative $\rho$ leads to a negative left-hand side and a positive right-hand side and therefore the larger sign cannot hold and we have a contradiction. Therefore a negative $\rho$ has to be ruled out.

Case 2: Suppose $(r+\delta)<\beta<1$ and therefore $\ln (r+\delta)<\ln \beta<0$ and $-\ln (r+\delta)>-\ln \beta>0$, a value of $\rho$ slightly below unity yields a result free of contradiction. But it implies an elasticity of substitution that is very much larger than unity. Suppose that interest plus depreciation is .1 and beta is .3 then $\rho>.52288$ is required. This yields an elasticity of substitution of more than two.

Case 3: If $(r+\delta)>\beta>0, \ln (r+\delta)>\ln \beta,-\ln (r+\delta)<-\ln \beta$. The condition A.3 still requires a positive $\rho$ larger than unity to turn the sign around into that of A.3, and substitution goes again the wrong way.

By implication, only in case 2, with a high elasticity of substitution can we have $B<1$ and $s r>g$, and an instability without $D(0)>K(0)$. 


\section{Appendix B: Data}

\begin{tabular}{|c|c|c|c|c|c|}
\hline year & Korea & Thailand & Malaysia1 & Malaysia2 & Malaysia3 \\
\hline 1960 & -0.5675 & -2.56109 & 5.0828 & 2.676316 & -0.12155 \\
\hline 1961 & -0.84024 & -2.3335 & 5.069069 & 2.644411 & -0.17459 \\
\hline 1962 & -0.60482 & -2.11995 & 4.803805 & 2.494561 & -0.19025 \\
\hline 1963 & -0.31885 & -1.94965 & 4.495179 & 2.326328 & -0.19526 \\
\hline 1964 & -0.29005 & -1.76041 & 4.182174 & 2.156387 & -0.19887 \\
\hline 1965 & -0.24675 & -1.54824 & 3.762093 & 1.919386 & -0.22301 \\
\hline 1966 & -0.09465 & -1.28364 & 3.496076 & 1.764664 & -0.24834 \\
\hline 1967 & 0.032234 & -1.18196 & 3.350789 & 1.679991 & -0.26254 \\
\hline 1968 & 0.155591 & -1.05898 & 3.180018 & 1.578179 & -0.28418 \\
\hline 1969 & 0.245926 & -0.92335 & 2.786261 & 1.336095 & -0.34992 \\
\hline 1970 & 0.30818 & -0.82828 & 2.598117 & 1.224552 & -0.37241 \\
\hline 1971 & 0.383269 & -0.7672 & 2.447318 & 1.146068 & -0.36681 \\
\hline 1972 & 0.398258 & -0.68189 & 2.071773 & 0.976716 & -0.29644 \\
\hline 1973 & 0.343682 & -0.50331 & 1.309885 & 0.589176 & -0.24875 \\
\hline 1974 & 0.359612 & -0.37198 & 1.098507 & 0.516945 & -0.1592 \\
\hline 1975 & 0.404407 & -0.30176 & 1.149235 & 0.555295 & -0.13524 \\
\hline 1976 & 0.315592 & -0.23975 & 0.906621 & 0.406834 & -0.17424 \\
\hline 1977 & 0.260247 & -0.15063 & 0.728862 & 0.308528 & -0.18017 \\
\hline 1978 & 0.232561 & -0.07621 & 0.602741 & 0.250108 & -0.15988 \\
\hline 1979 & 0.261922 & 0.00938 & 0.421456 & 0.149532 & -0.16662 \\
\hline 1980 & 0.347978 & 0.072144 & 0.376282 & 0.140717 & -0.13316 \\
\hline 1981 & 0.369266 & 0.140744 & 0.464807 & 0.234109 & -0.03411 \\
\hline 1982 & 0.370422 & 0.161514 & 0.566192 & 0.350915 & 0.100627 \\
\hline 1983 & 0.346755 & 0.219546 & 0.622544 & 0.43109 & 0.2085 \\
\hline 1984 & 0.32373 & 0.260395 & 0.601754 & 0.43181 & 0.234226 \\
\hline 1985 & 0.319457 & 0.319484 & 0.674733 & 0.489846 & 0.27489 \\
\hline 1986 & 0.232604 & 0.282633 & 0.763451 & 0.555461 & 0.313645 \\
\hline 1987 & 0.109158 & 0.24823 & 0.590346 & 0.407811 & 0.19559 \\
\hline 1988 & 0.00156 & 0.229362 & 0.485686 & 0.319143 & 0.125515 \\
\hline 1989 & -0.02325 & 0.230741 & 0.432874 & 0.281664 & 0.105862 \\
\hline 1990 & -0.01288 & 0.280592 & 0.400996 & 0.267563 & 0.112429 \\
\hline 1991 & 0.01691 & 0.321262 & 0.444417 & 0.324861 & 0.18586 \\
\hline 1992 & 0.028542 & 0.339702 & 0.405814 & 0.306504 & 0.191044 \\
\hline 1993 & 0.023156 & 0.353197 & 0.40354 & 0.315726 & 0.21363 \\
\hline 1994 & 0.029301 & 0.361936 & 0.423539 & 0.344669 & 0.252972 \\
\hline 1995 & 0.041063 & 0.391339 & 0.452558 & 0.386431 & 0.309548 \\
\hline 1996 & 0.083272 & 0.441521 & 0.443009 & 0.384762 & 0.317042 \\
\hline 1997 & 0.10485 & 0.541617 & 0.50553 & 0.446886 & 0.378705 \\
\hline 1998 & 0.030153 & 0.603538 & 0.567102 & 0.485713 & 0.391087 \\
\hline 1999 & -0.03703 & 0.451559 & 0.338478 & 0.264155 & 0.177744 \\
\hline 2000 & -0.05741 & 0.378984 & 0.08705 & 0.021533 & -0.05464 \\
\hline
\end{tabular}

Source: Own calculations based on Table 1 and World Development Indicators 2002. 
Table 1

Calculation of initial values for stocks of net debt

Variable Korea Thailand Malaysia1 Malaysia2

income credit

$\begin{array}{llll}553 & 636 & 739 & 739\end{array}$

$\begin{array}{lllll}\text { income debit } & 2655 & 865 & 1575 & 1575\end{array}$

net payments

(a)

$$
2102
$$

229

836

836

interest paid

2863

814

589

589

total gross debt

29480

8297

6611

6611

interest rate (b)

0.0971

0.098

0.089

0.238

initial value (c ) $21647.79 \quad 2334.168 \quad 9383.355 \quad 3509.077$

Notes:

(a) Difference of rows 2 and 1; data for 1980 in millions of US dollars are from IMF IFSY 1996, 1997.

(b) Row 4 divided by row 5; data for 1980 in millions of US dollars are from Global Development Finance 2003

( c ) Net payment from row 3 divided by interest rate from row 6 
Table 2 Simple debt dynamics regressions 1961-2000

\begin{tabular}{|c|c|c|c|c|c|c|}
\hline \multirow{3}{*}{ Intercept } & \multirow{2}{*}{$\begin{array}{r}\text { Korea } \\
0.02\end{array}$} & \multicolumn{2}{|c|}{ Thailand } & \multicolumn{3}{|c|}{ Malaysia2 } \\
\hline & & 0.04 & 0.05 & 0.05 & -0.01 & 0.00 \\
\hline & $(1.21)$ & (3.48) & (5.57) & (3.71) & $-(0.21)$ & - \\
\hline \multirow[t]{2}{*}{ debt $(-1)$} & -0.11 & -0.19 & -0.08 & -0.09 & -0.07 & -0.06 \\
\hline & $-(1.84)$ & $-(5.49)$ & $-(9.23)$ & $-(4.64)$ & $-(3.26)$ & $-(2.74)$ \\
\hline \multirow[t]{2}{*}{ d(debt(-1)) } & - & 0.28 & 2.75 & 0.37 & & 0.51 \\
\hline & & $-(2.75)$ & & $(2.44)$ & & (3.27) \\
\hline \multirow[t]{2}{*}{ d(debt(-2)) } & - & - & & -0.44 & & -0.45 \\
\hline & & & & $-(2.42)$ & & $-(2.51)$ \\
\hline d(debt(-3)) & - & - & & - & & $\begin{array}{r}0.32 \\
(1.97)\end{array}$ \\
\hline \multicolumn{2}{|c|}{$\begin{array}{l}\text { MacKinnon one sided } p \text { - } \\
\text { value }\end{array}$} & 0.00 & & 0.00 & & 0.01 \\
\hline Adj $R^{2}$ & 0.10 & 0.49 & 0.68 & 0.69 & 0.22 & 0.46 \\
\hline SE of regression & 0.09 & 0.06 & 0.05 & 0.04 & 0.10 & 0.08 \\
\hline Durbin-Watson & 1.18 & 1.04 & 1.37 & 2.09 & 1.11 & 1.89 \\
\hline
\end{tabular}


Figure 1 Three different regimes for debt/GDP dynamics

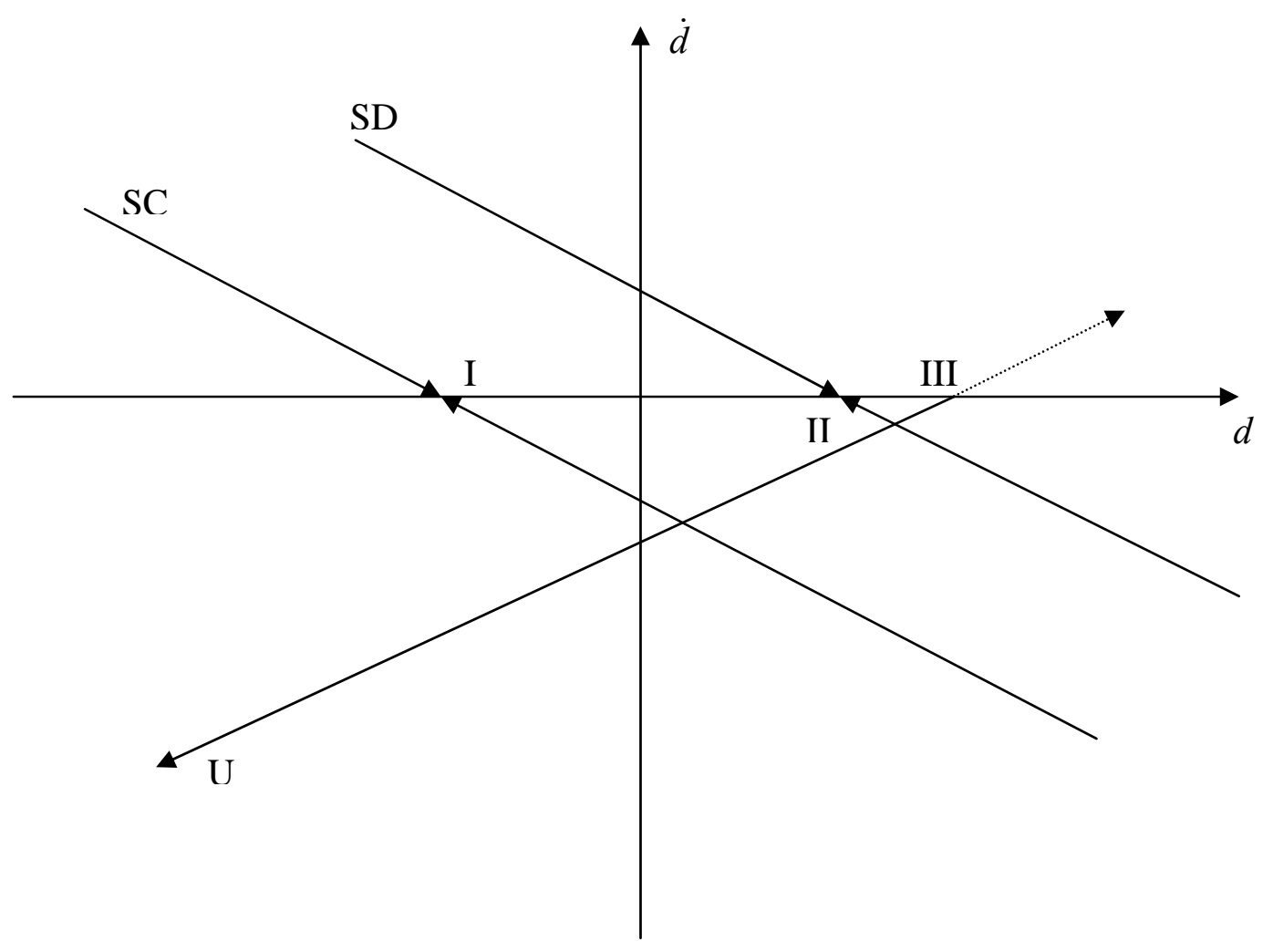


Figure 2 Asian Debt/GDP Ratios 1960-2000
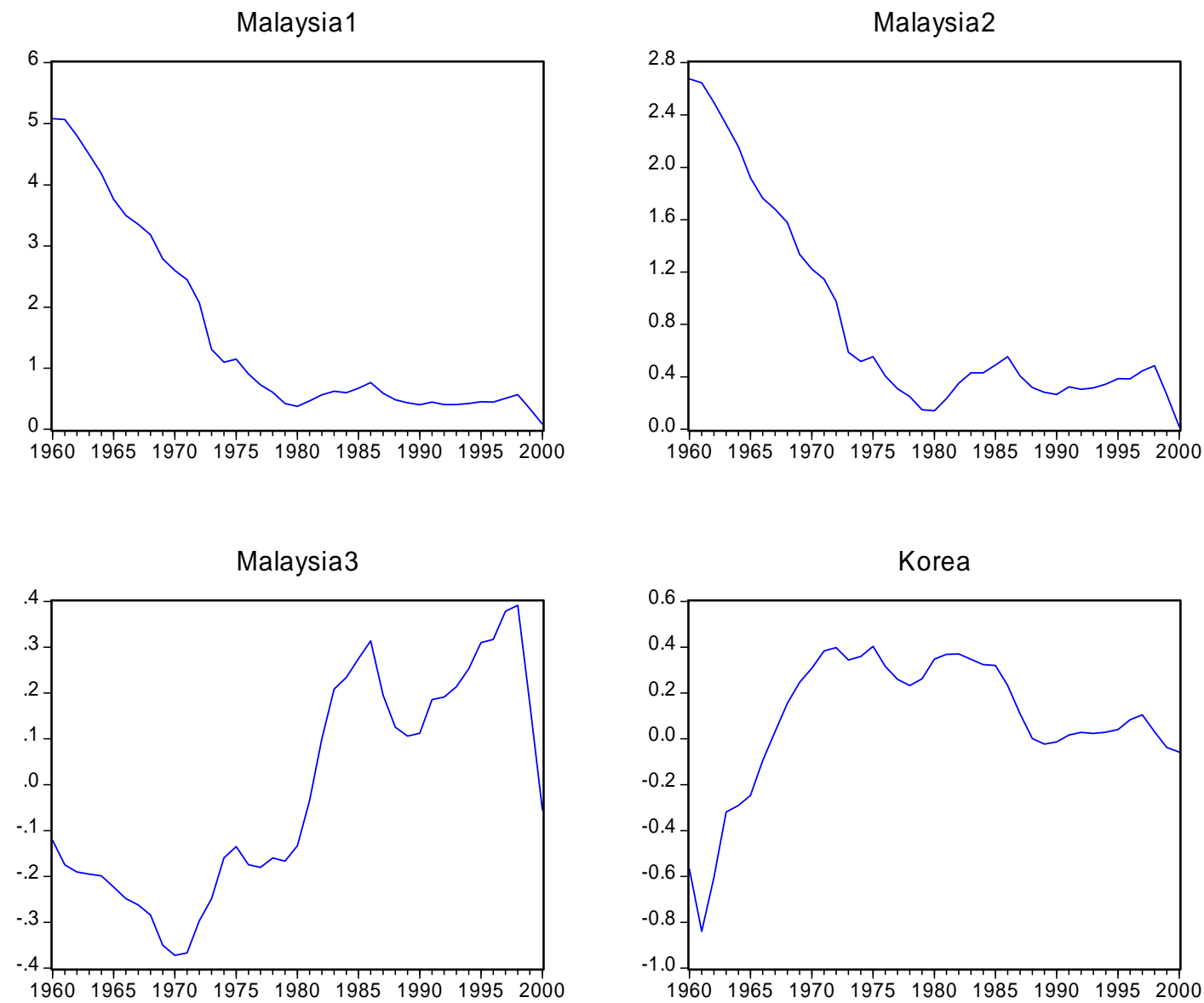

Thailand

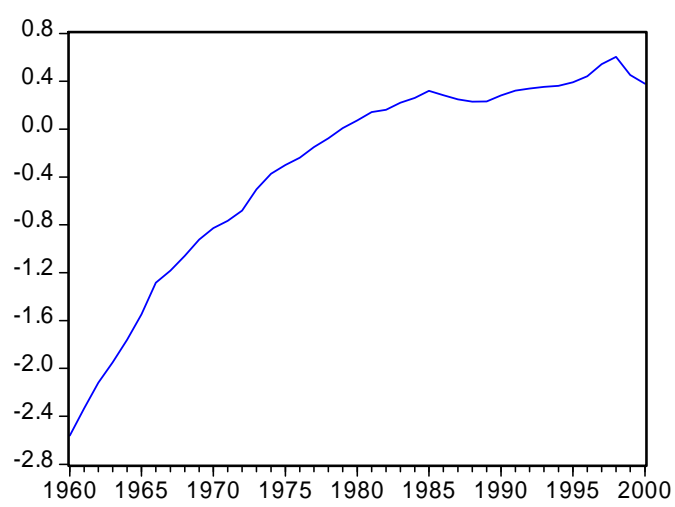

Source: Own calculations for alternative initial values 
Table 3

Period

Six years windows

1988-93

1989-94

1990-95

1991-96

1992-97

Seven years

windows

1987-93

1988-94

1989-95

1990-96

1991-97

Eight years windows

1986-93

1987-94

1988-95

1989-96

1990-97

Rolling windows results for

Korea

Constant t-value $\mathrm{d}(-1)$

(-1) t-value adj.Rsq.

$\begin{array}{llrrr}0.004 & 0.359 & -0.940 & -11.452 & 0.782 \\ 0.006 & 0.787 & -0.295 & -1.766 & -0.111 \\ 0.014 & 4.601 & -0.294 & -1.665 & 0.180 \\ 0.018 & 2.145 & -\mathbf{0 . 0 8 2} & -0.165 & -0.240 \\ 0.004 & 0.493 & 0.277 & 2.256 & -0.035\end{array}$

$\begin{array}{lrrrr}0.001 & 0.061 & -0.610 & -9.001 & 0.801 \\ 0.008 & 0.645 & -0.934 & -8.556 & 0.752 \\ 0.007 & 1.017 & -0.186 & -0.878 & -0.137 \\ 0.015 & 3.540 & 0.023 & 0.076 & -0.199 \\ 0.016 & 2.010 & 0.030 & 0.180 & -0.196\end{array}$

$\begin{array}{rrrrr}-0.004 & -0.280 & -0.387 & -4.495 & 0.623 \\ 0.004 & 0.312 & -0.619 & -10.461 & 0.799 \\ 0.011 & 0.949 & -0.913 & -6.101 & 0.690 \\ 0.008 & 1.137 & 0.152 & 0.417 & -0.134 \\ 0.015 & 2.965 & 0.061 & 0.532 & -0.146\end{array}$




\begin{tabular}{|c|c|c|c|c|c|}
\hline Table 4 & Rolling $\mathrm{n}$ & ows res & $s$ for The & and & \\
\hline Period & constant & t-value & $\mathrm{d}(-1)$ & t-value & adj.Rsq \\
\hline Six years & & & & & \\
\hline 1988-93 & 0.013 & 0.172 & 0.017 & 0.064 & -0.249 \\
\hline $1989-94$ & 0.061 & 1.262 & -0.133 & -0.816 & -0.072 \\
\hline $1990-95$ & 0.111 & 3.904 & -0.268 & -2.995 & 0.614 \\
\hline $1991-96$ & 0.010 & 0.136 & 0.049 & 0.232 & -0.233 \\
\hline $1992-97$ & -0.242 & -4.868 & 0.756 & 5.639 & 0.860 \\
\hline Seven ye & & & & & \\
\hline $1987-93$ & 0.014 & 0.158 & -0.013 & -0.043 & -0.200 \\
\hline $1988-94$ & 0.023 & 0.403 & -0.025 & -0.123 & -0.196 \\
\hline $1989-95$ & 0.048 & 1.138 & -0.081 & -0.593 & -0.121 \\
\hline $1990-96$ & 0.064 & 1.447 & -0.104 & -0.775 & -0.071 \\
\hline 1991-97 & -0.113 & -1.578 & 0.422 & 2.119 & 0.368 \\
\hline Eight yea & & & & & \\
\hline $1986-93$ & 0.047 & 0.539 & -0.151 & -0.496 & -0.121 \\
\hline $1987-94$ & 0.014 & 0.207 & -0.015 & -0.063 & -0.166 \\
\hline 1988-95 & 0.011 & 0.233 & 0.022 & 0.135 & -0.163 \\
\hline $1989-96$ & 0.019 & 0.478 & 0.023 & 0.180 & -0.160 \\
\hline $1990-97$ & -0.022 & -0.374 & 0.179 & 1.051 & 0.015 \\
\hline
\end{tabular}


Table 5

Period

Six years windows

1988-93

1989-94

1990-95

1991-96

1992-97

Seven years

windows

1987-93

1988-94

1989-95

1990-96

1991-97

Eight years windows

1986-93

1987-94

1988-95

1989-96

1990-97
Rolling windows results for Malaysia

Constant t-value $\mathrm{d}(-1) \quad \mathrm{t}$-value adj.Rsq.

$\begin{array}{rrrrr}0.264 & 5.079 & -0.877 & -6.283 & 0.741 \\ 0.272 & 2.540 & -0.886 & -2.423 & 0.177 \\ 0.047 & 0.277 & -0.098 & -0.170 & -0.240 \\ 0.140 & 2.573 & -0.371 & -2.056 & 0.089 \\ -0.076 & -0.744 & 0.281 & 0.960 & -0.114\end{array}$

$\begin{array}{lllll}0.184 & 5.926 & -0.621 & -9.061 & 0.846 \\ 0.272 & 6.635 & -0.884 & -8.645 & 0.645 \\ 0.082 & 0.441 & -0.235 & -0.375 & -0.162 \\ 0.072 & 1.215 & -\mathbf{0 . 1 8 0} & -0.938 & -0.126 \\ 0.047 & 0.620 & \mathbf{- 0 . 0 6 5} & -0.277 & -0.190\end{array}$

$\begin{array}{rrrrr}0.100 & 1.868 & -0.331 & -1.832 & 0.111 \\ 0.197 & 7.132 & -0.642 & -11.399 & 0.813 \\ 0.236 & 4.271 & -0.745 & -3.785 & 0.360 \\ 0.067 & 0.894 & -\mathbf{0 . 1 8 4} & -0.761 & -0.116 \\ -0.005 & -0.084 & 0.080 & 0.393 & -0.152\end{array}$


Figure 3
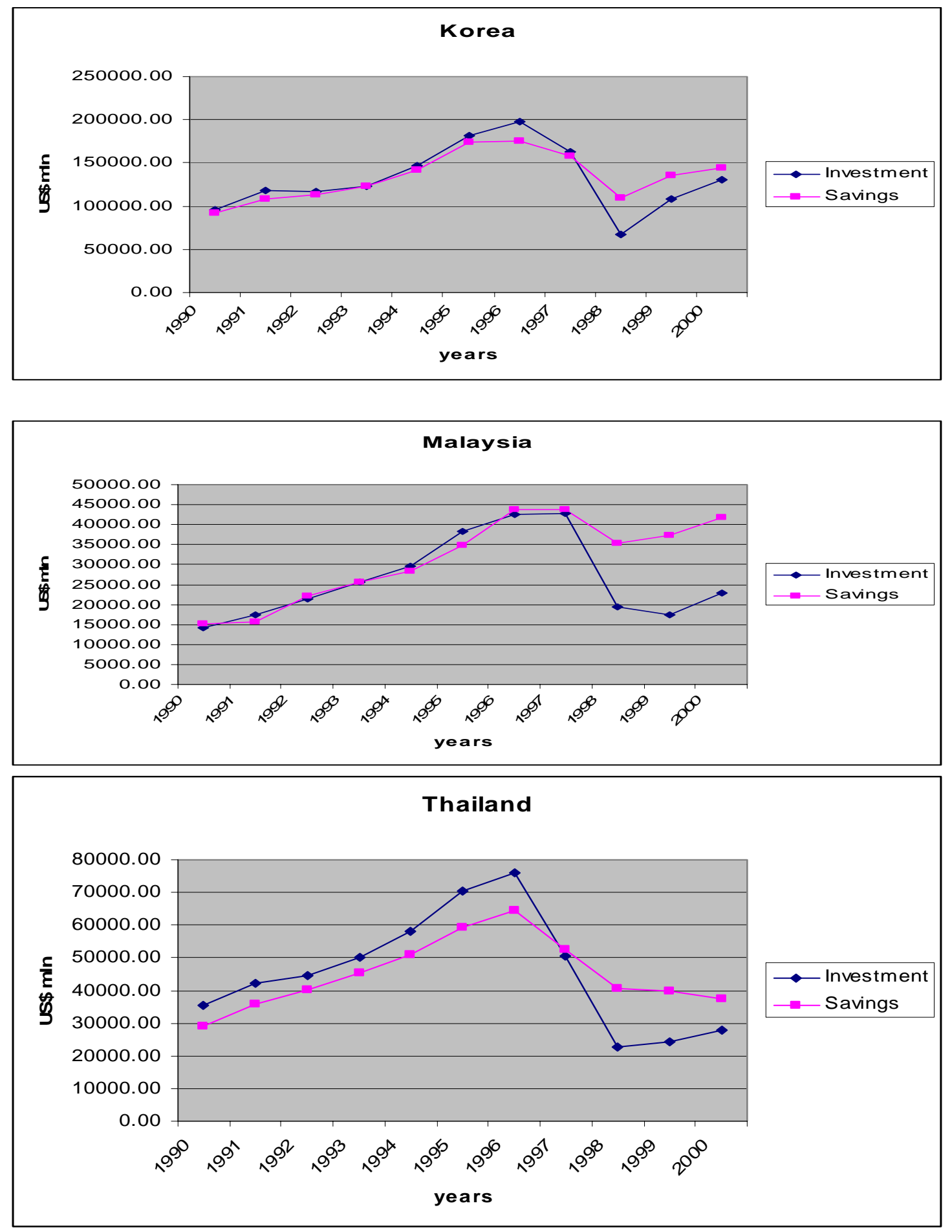

Source: World Development Indicators 2002 
Figure 4

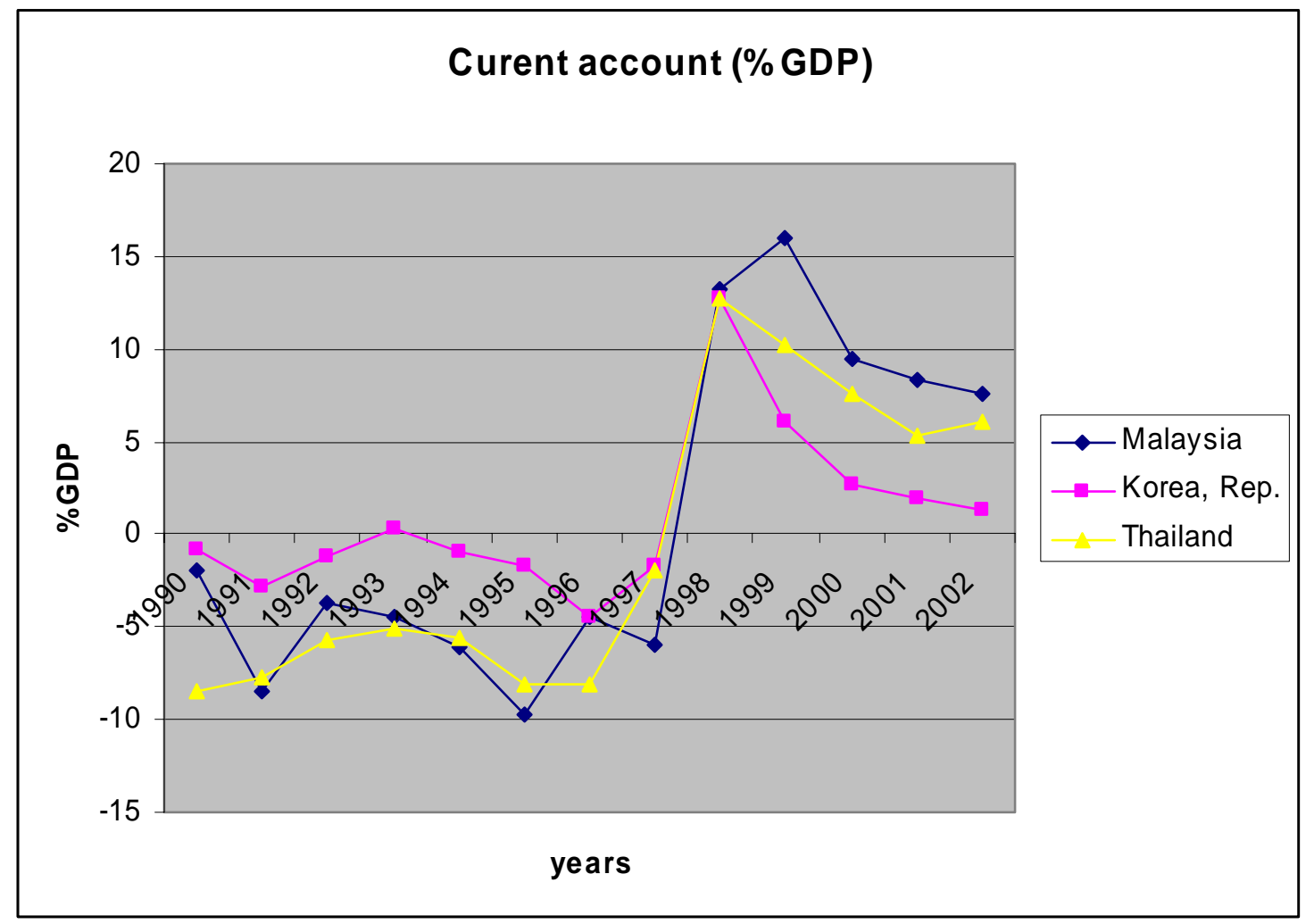

Source: World Development Indicators 2004 
Figure 5

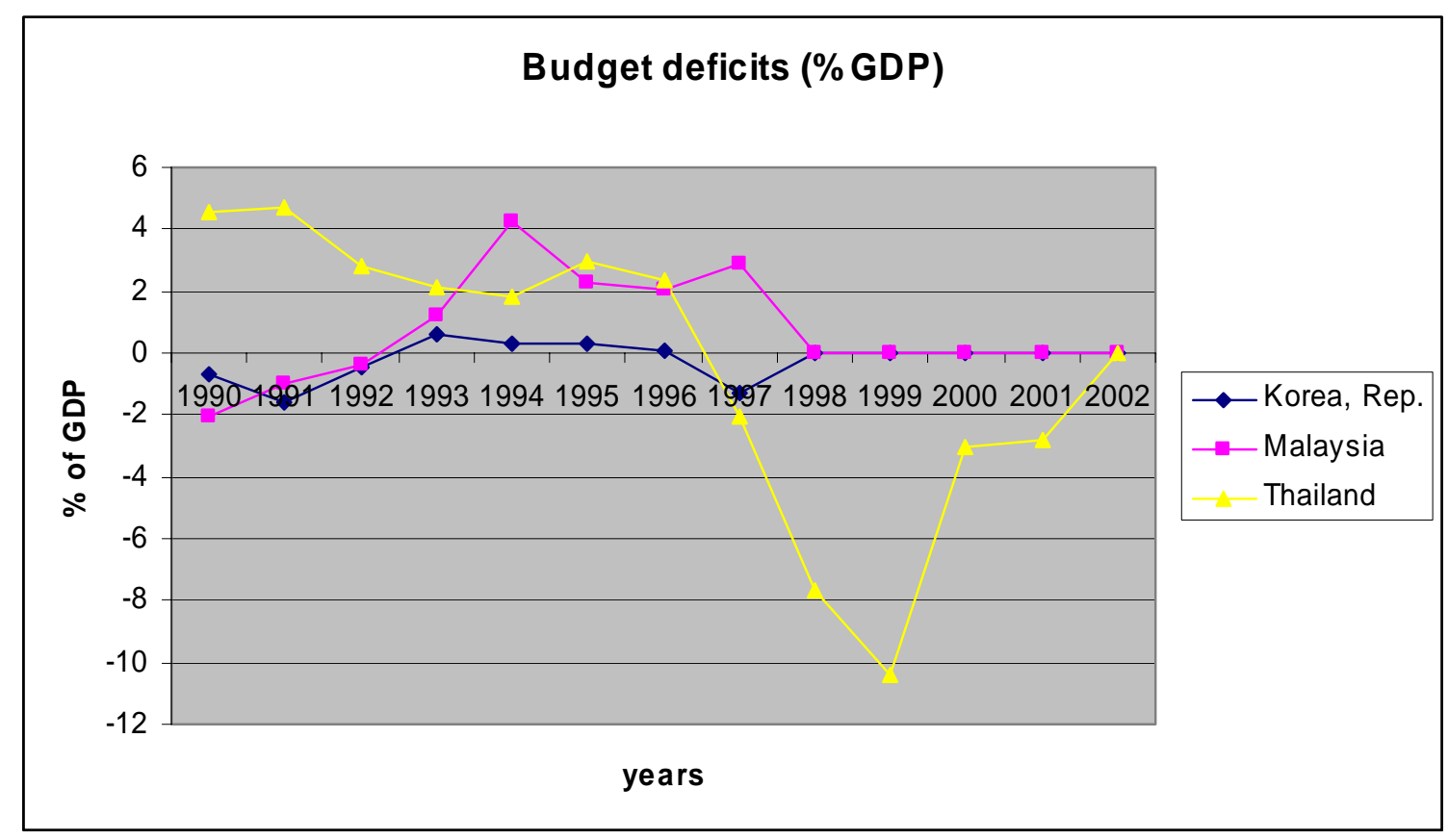

Source: World Development indicators 2004 